IWONA KABZIŃSKA

Institute of Archaeology and Ethnology, Polish Academy of Sciences, Warsaw

\title{
THE DYING OF CZERNIAKOWSKIE LAKE, THE DYING OF QUIET: \\ FROM A HI-FI TO A LO-FI SOUNDSCAPE
}

\section{HI-FI AND LO-FI SOUNDSCAPES}

Research conducted in the 1970s by the Canadian musicologist and composer Raymond Murray Schafer ${ }^{1}$ played a key role in the development of studies on the ecology of sound, soundscapes, the phonosphere, acoustic communities, and so forth. The term "soundscape", which he used, came to be especially popular. The soundscape is a focus of study in many countries. In Poland, one of the centers engaged in this kind of research is the Cultural Studies Institute of the University of Wrocław. Since 2004 it has conducted seminars on the subject, including one on "Selected Issues of the Audiosphere in Wrocław and Lower Silesia" (Losiak 2012b, p. 13) ${ }^{2}$. In 2009, the Institute inaugurated the Interdisciplinary Workshop for Soundscape Research (ibidem). Research concerning the soundscape has also been conducted by employees of the Institute of Earth Sciences of Maria Curie-Skłodowska University and members of the Cultural Landscape Committee of the Polish Geographical Society. On their initiative, a nationwide interdisciplinary seminar entitled "Sound in the Landscape - the Current State of Research and Perspectives" was held in 2008 (ibidem, pp. 12-13; for studies on the soundscape conducted in Poland, see also, for instance, Bernat 2011; Bernat 2015; Harbanowicz, Janiak (eds.) 2012; Losiak 2008; 2012a; 2012b; 2015; Losiak, Tańczuk (eds.) 2012; Stanisz 2017).

My writings deal primarily with quiet and noise, the impact of these phenomena, their connection with individual people's behavior and with interpersonal relations (for instance, between neighbors), the changes caused when the noise around and inside us increasingly drives out the quiet, and the experience of and attitudes toward these changes (Kabzińska 2005; 2007; 2009; 2012; 2018). I am interested in the hi-fi or lo-fi classification of soundscapes, which was introduced by Schafer.

\footnotetext{
${ }^{1}$ See, e.g., Schafer 1970; 1973; 1977; 1982.

2 The studies concerned, among other things, "reception of the audio sphere of the city, the presence of music in the public sphere of the city, the sounds of temples, documentation and phonic analysis of selected holiday events in the municipal space, and planning phonic walking paths" (Losiak 2012b, p. 13, footnote 5; see also Losiak 2008).
} 
Generally speaking, a hi-fi soundscape contains natural sounds, recognizable as acoustic signals; there is room in such a soundscape for quiet (Schafer 1982, p. 296; after Losiak 2012a, pp. 12-13). The lo-fi space is dominated by "mechanical", artificial, "annoying" sounds and characterized by "monotony [...] and homogenous noise" (Losiak 2012a, p. 15). What is involved is "a phonic "pressure» [...] [which] prevents or significantly hampers the proper recognition of acoustic signals" (ibidem, p. 12). A lo-fi phonic space is characterized by "aggressive[ness] [and] expansive[ness]" (ibidem, p. 13). The birth of such spaces is related to the development of industry (ibidem), whose continual expansion has led, among other things, to the replacement of hi-fi soundscapes with lo-fi soundscapes. The factors that have favored such a change are the tempo of urbanization, new types of infrastructure construction (for transportation, trade, and entertainment), and the development of electronics (for instance, the production of various kinds of amplification equipment, music players, etc.). An increasing number of people find themselves under the pressure of very strong stimuli, including sound stimuli; they become dependent on these stimuli, and no longer experience, or want to experience, silence (see further: Kabzińska 2018; Kagge 2017; Sarah, Diat 2017).

Schafer regarded the lo-fi soundscape as a threat to hearing and a source of environmental "pollution". Some researchers do not share his view. According to Robert Losiak, for instance, a city without hubbub would be inhuman (Losiak 2012a, pp. 15-20). He also considers there is no need for a determined battle to eliminate the lo-fi phenomenon. Many people accept this kind of phonic landscape as an element of their familiar near environment (ibidem, p. 15-19). The "daily hum" suits them; they like a "noise-saturated place", "pulsating with life" (ibidem, p. 18). They associate the hi-fi soundscape with the "atmosphere of a housing estate in a small town", with boredom and the slow passage of time (ibidem). It could be said that lo-fi has become a synonym of modernity, progress, and contemporary culture, while hi-fi is connected with backwardness.

"Noise is one of the most frequently mentioned causes for a lowered quality of life" (Bernat 2011, p. 200). How can this fact be made to accord with the growing number of adherents of a lo-fi soundscape, which as Losiak writes (2012a, p. 21), constitutes "a kind of phenomenon of the contemporary audio sphere of a city"? This scoundscape is formed by "modern office districts, transportation routes, trade and entertainment centers, and industrial architecture" (ibidem, pp.19-20). It is connected with "street traffic, the noise of stations, offices, and agencies, shopping centers and sidewalks, as well as pubs, schools, and stadiums" (ibidem, p. 20). Losiak favors separating the lo-fi soundscape from housing settlements, recreation areas, and "nature [...] areas" (ibidem, p. 19). I would like to point out that in practice such a separation is very difficult. The lo-fi neighborhood becomes a torture for people who value quiet and are particularly sensitive to noise. It can also be a source of conflicts. For example, entertainment zones are often located in the near vicinity of housing settlements. They are often considered, by advocates of noisy entertainment, to be part of the attraction of modern cities, an answer to the needs of its inhab- 
itants, particularly those of the young generation, who can only amuse themselves in the midst of noise. However, not everyone is in favor of, or accepting of, such an approach (see further, Kabzińska 2009, pp. 82-93).

\section{CZERNIAKOWSKIE LAKE: \\ A BRIEF HISTORY OF ITS PROGRESSIVE DESICCATION}

In my opinion, in the near future Czerniakowskie Lake and the terrain in its immediate vicinity will be an example of the transformation of a hi-fi soundscape to a lo-fi soundscape ${ }^{3}$. The lake is one of the distinguishing landscape features of the Garden City of Sadyba (part of the Warsaw district of Mokotów) ${ }^{4}$. It is the "largest old Vistula riverbed within the borders of Warsaw. It forms part of the old riverbed complex that stretches as far as Wilanów [...]". This "largest natural body of water" within the capital's borders has a surface area of 19.5 hectares, a length of 1,780 meters, and a width of 100-180 meters, with an "average depth of 2.5 meters and a maximum depth of 3.75 meters" . On the southwestern side of Czerniakowskie Lake the floodplain terrace has "a sandy embankment of around three meters. The area on the side of Jeziorna Street has been made into a beach"7. On hot, sunny days, the place draws crowds of people for swimming, sunbathing, barbecuing, walks, and other entertainments.

Members of the older generation of Sadyba inhabitants, who have lived in this part of Warsaw since their childhood, remember Czerniakowskie Lake as their favorite place to play (Caillot Dubus, Karkowska 2015, pp. 56, 59, 89, 123, 131). Many people also remember buying dairy products, bread, and fruits from the inhabitants of nearby villages, or from people coming to Sadyba from further away (ibidem, p. 79) ${ }^{8}$;

${ }^{3}$ We observe this phenomenon to an ever greater degree in, e.g., rural areas (see, e.g., Dziekanowska 2015; Kabzińska 2018, pp. 15-17; Malec, Klatka, Kruk, Ryczek 2017).

${ }^{4}$ The Garden City of Sadyba was established in the 1920s according to a plan of the well-known architects Kazimierz Tołłoczko, Tadeusz Tołwiński, and Aleksander Więckowski, in reference to Ebenezer Howard's turn of the nineteenth to twentieth-century concept of garden cities (further see, Bronowicz 2001; Faryna-Paszkiewicz, Paszkiewicz 1985; Kasprzycki, Stępień 1982, pp. 46-47).

${ }^{5}$ Hall Karolina, Rezerwat Jeziorko Czerniakowskie. Problem „miejskich” obszarów chronionych, http:// panorama.varsovia.pl/varsovia/index.php-frame+=ain\&map..., accessed 03.09.2018, "the combined area of the scenic reserve of Czerniakowskie Lake is 46.83 hectares" (ibidem).

${ }^{6}$ Rezerwat przyrody Jeziorko Czerniakowskie, June 24, 2018, https://pl.wikipedia.org/wiki/Rezerwat_przyrody_Jeziorko_Czerni..., accessed 03.09.2018.

7 Rezerwat przyrody Jeziorko Czerniakowskie, June 24, 2018, https://pl.wikipedia.org/wiki/Rezerwat_przyrody_Jeziorko_Czerni..., accessed 03.09.2018.

${ }^{8}$ A woman (age 74), with whom I spoke in the summer of 2018, said that near the church of the Bernardines there had been peasant dwellings. Her mother bought eggs, cream, and "real" milk, which was allowed to turn sour (then a "thick crust of cream" formed on it). Fruit trees grew by the houses, mostly apple trees. They had apples of various kinds, for instance, Kosztelas, "whose juice is good for heart problems"), Calvilles and Polish Paper apples, which had an "unusual crispness, taste, and scent. Such apples can't be found today". The woman considered that "in the shops they don't give any 
or they remember elements of the landscape (a ditch, a tree, the flowers in home gardens, the lake, cultivated fields, stacks of grain, the poppies and cornflowers growing in the grain fields, the cows feeding in the meadows) ${ }^{9}$. The sounds remembered from childhood include the sound of parents calling to children to leave their play in the courtyard and come home for lunch or dinner (ibidem, p. 73), the voice of a knifegrinder hawking his services (ibidem, p. 79), and the clip-clop of a horse pulling a wagon over the cobblestone streets (ibidem). One person remembered the "rumble of a bus standing at the bus terminal near the house. The batteries were weak, so the driver did not turn the engine off at the stop. The motor rumbled loudly. The shrill sound of the sewage truck was worse, though; it always came at the break of dawn and brought all the inhabitants to their feet" (ibidem, p. 89). Every so often, the whistle of a steam engine pulling train cars would be heard in the Garden City. This was the "famous Wilanów «choo-choo»", which traveled "through field and meadow as far as Plac Unii Lubelskiej" (Wrzeszcz 2000, p. 33) ${ }^{10}$. The sounds coming from the tennis courts are still characteristic of Sadyba. Sometimes the courts were used in the very early morning, rousing the neighbors. What for some was a game, a recreation, for others caused annoyance and lack of sleep ${ }^{11}$.

In the interwar period, floods were still a frequent phenomenon as a result of heavy rains and the Lake's connection with the waters of the Vistula, which was only around two kilometers away ${ }^{12}$. Now the level of water in the lake has been systematically declining for many years. The lake is drying and being overgrown at lightening speed. According to Michał Wasilewicz of the Department of Biology and Environmental Engineering of the Warsaw University of Life Sciences (cited by Michał Wojtczuk), humans are to blame. "It began in 1873 already. At that time, the banks of the Vistula were regulated in order to build a water intake for the emerging Warsaw

information about the kind of apple. What is sold is simply «apples»" I said that the sellers in bazaars and small shops place the name of the apple variety in the box with the apples. I also confirmed that in large shops there is no such practice. Another woman, who as a child used to come to Sadyba from another district of Warsaw to visit her uncle's family in the 1950s, also remembered the orchard fruit, the delicious Paper apples, the peasant huts where dairy products could be bought, the meadows by the lake, and the trees growing thickly in the Garden City of Sadyba. This same woman said that where Konstancińska Street is now located there was a field of cabbage in her childhood. Many older people observed that in the past Czerniakowskie Lake was not overgrown as it is at present. I conducted the conversations during the course of research on the subject of "Quiet and Noise in the City Space: Warsaw's Sadyba and Its Vicinity" (research project at the Institute of Archaeology and Ethnology of the Polish Academy of Sciences in 2017-2020).

9 For the connection between sounds, memory, and experience, see, e.g., Stanisz 2017, p. 3.

${ }_{10}$ Another interlocutor (age 74) also remembered the bygone train that ran between Wilanów and Plac Unii until the 1960s.

${ }_{11}$ Urzykowski Tomasz, June 8, 2008, Oficerska Sadyba i Miasto Ogród Czerniaków, http://warszawa. wyborcza.pl/warszawa/1,89378,5193535.html, pp. 25-26, accessed December 07.12.2017.

${ }_{12}$ Ekspertyza - bilans wody Jeziorka Czerniakowskiego w Warszawie, 2009, Dariusz Górski, Katedra Inżynierii Wodnej i Rekultywacji Środowiska SGGW, Warsaw, www.mokotow.waw.pl/mokotow/web/ uploads/pub/pages/page_366/text_images/Ekspertyza..., p. 4, accessed 01.10.2018. The authors refer, among others, to Gumiński, Jasińska, Kobendza 1925. 
water mains system. Earlier the river had divided into several branches, one of which had become the lake. When the Vistula was regulated it was separated from the lake by nearly a kilometer and a half, and thus the lake was no longer fed by the river"13.

In the 1920s, "[flood] dike[s] were built on the Siekierkowski Loop"14. Today the body of water is supplied chiefly by groundwater. In the 1960s and 1970s the course of the groundwater was cut by mains serving the apartment housing settlement on Bernardyńska street"15. Part of the underground water is diverted and does not return to the lake ${ }^{16}$. Another cause of the lake's desiccation is the "lowering of the Vistula corridor. Over the course of 120 years, the bottom has lowered by as much as four meters. Among other things, this is the result of selling river sand for construction"17. "Today, the groundwater runs more deeply than in the past"18. The near vicinity of the Siekierki Hydro-Electric Plant is not beneficial for the lake ${ }^{19}$. The power station was built in 1961, on "wetlands, and in order to ensure the stability of the buildings, water drains work full time there to get rid of the water. They drain the ground waters, which instead of flowing to the lake are thrown into the Vistula"20. The drying of the lake, the overgrowth of its banks, and the worsening quality of the water is also caused by drought, "the illegal connection of sewage mains to the storm drain network, and [...] the permeability of the sewage system"21. The waters of the lake have a "high, sometimes extremely high, concentration of nitrogen and phosphorous. Given the lack of oxygen in the lower layers of water, these compounds form excellent conditions for the growth of algae"22. For a long time, the lake has been systematically polluted by illegal sewage outlets ${ }^{23}$; it has become a garbage dump; "fish poaching" 24

${ }_{13}$ Wojtczuk Michał, May 29, 2017, Jeziorko Czerniakowskie wysycha. Bez zasilania po prostu zniknie, http://warszawa.wyborcza.pl/warszawa/7,54420,21877967,jeziorko..., accessed 03.0.2018.

${ }^{14}$ Ibidem.

${ }^{15}$ Ibidem.

16 Ibidem.

17 Ibidem.

${ }^{18}$ Ibidem, cf. Ekspertyza - bilans wody Jeziorka Czerniakowskiego w Warszawie, 2009, Dariusz Górski, Katedra Inżynierii Wodnej i Rekultywacji Środowiska SGGW, Warsaw, www.mokotow.waw.pl/ mokotow/web/uploads.pub/pages/page_366/text_images/Ekspertyza..., p. 4, accessed 01.10.2018; Hall Karolina, Rezerwat Jeziorko Czerniakowskie. Problem „miejskich” obszarów chronionych, http://panorama. varsovia.pl/varsovia/index.php-frame+main\&map..., accessed 03.09.2018.

${ }_{19}$ Rezerwat przyrody Jeziorko Czerniakowskie, June 24, 2018, https://pl.wikipedia.org/wiki/Rezerwat_przyrody_Jeziorko_Czerni..., accessed 03.09.2018.

${ }_{20}$ Wojtczuk Michał, May 29, 2017, Jeziorko Czerniakowskie wysycha! Bez zasilania po prostu zniknie, http://warszawa.wyborcza.pl/warszawa/7,54420,21877967,jeziorko..., accessed 03.09.2018.

${ }^{21}$ Raport SGGW - Wysychanie Jeziorka Czerniakowskiego radykalnie przyspieszyło, October 17, 2016, Wydział Budownictwa i Inżynierii Środowiska SGGW, Warsaw. The report was prepared by a team under the direction of Michał Wasilewicz, www.sadyba24.pl/component,/k2/item/1400-tylko-u-nas-raportSGGW-wysychanie-jeziorka-czerniakowskiego-radykalnie-przyspieszyło, accessed 11.12.2017.

${ }^{22}$ Ibidem.

${ }^{23}$ Jeziorko Czerniakowskie wysycha! Jeśli nie będzie zasilane w wodę to zaniknie!, February 27, 2017, https://imokotow.pl/artykul/jeziorko-czerniakowskie/139753, accessed 04.10.2018.

${ }^{24}$ Jeziorko Czerniakowskie wysycha! Jeśli nie będzie zasilane w wodę to zaniknie!, https://imokotow. pl/artykul/jeziorko-czerniakowskie/139753, accessed October 4, 2018. 
has become a common sight. Various plans for saving the lake have been produced, but the cost of implementing them is very high. Scientists are also not in agreement as to which method would be the most effective ${ }^{25}$.

A segment of the population of the Garden City of Sadyba blames the drying of the lake on the construction of housing settlements in its vicinity ${ }^{26}$. In the 1970s, the Bernardyńska housing settlement ${ }^{27}$ was erected on the meadows between Powsińska Street and Czerniakowskie Lake. Toward the end of the 2000s, a settlement of sixstory houses with underground garages ${ }^{28}$ was built "just beyond the border of the nature preserve of Czerniakowskie Lake, but within its immediate environment" 29 . The investment proceeded in spite of numerous protests, including by ecologists and part of Sadyba's inhabitants ${ }^{30}$. Above all, the protesters criticized the plan to build

${ }^{25}$ See, e.g., Raport SGGW - Wysychanie Jeziorka Czerniakowskiego radykalnie przyspieszyło, October 17, 2016, Wydział Budownictwa i Inżynierii Środowiska SGGW, Warsaw, www.sadyba24.pl/component,/ $\mathrm{KZ/ite,/1400} \mathrm{-} \mathrm{tylko-u-nas-raportpsggw-wysychanie-jeziorka-czerniakowskego-radykalnie-przyspieszyło,}$ accessed 11.12.2017; See also: http://mokotow.waw.pl/strona-363-ekspertyzy_i_publikacje.html, accessed 11. 12. 2017; see also: Ekspertyza - bilans wody Jeziorka Czerniakowskiego w Warszawie, 2009, Dariusz Górski, Katedra Inżynierii Wodnej i Rekultywacji Środowiska SGGW, Warsaw, www.mokotow.waw.pl/ mokotow/web/uploads/pub/pages/page_366/text_images/Ekspertyza, accessed 01.10.2018; Wojtczuk Michał, May 29, 2017, Jeziorko Czerniakowskie wysycha! Bez zasilania po prostu zniknie, http://warszawa. wyborcza.pl/warszawa/7,54420,21877969,jeziorko..., accessed 03.0.2018.

${ }^{26}$ Jeziorko Czerniakowskie wysycha! Jeśli nie będzie zasilane w wodę, to zaniknie!, February 27, 2017, https://mokotow,pl/artykul/jeziorko-czerniakowskie/139753, accessed 04.10.2018. On June 16, 2018, I took part, with over a dozen other people, in a walk along Bernardyńska Street organized by the Garden City of Sadyba Association. One of the participants remembered that in the period when the Bernardyńska settlement was built, the canals that then existed were filled in. The result was the drying of the lake, which was deprived of its natural inflows of water. A man added that the connection of the lake with the Wilanów Canal has not been cleaned for years, and this has also contributed to the systematic lowering of the water level in the lake. A 75-year-old woman, with whom I had spoken in the summer of 2018, said that "the Lake was connected with the Vistula. The level of the water was high; when the Bernardyńska settlement began to be built, the water began to dry up. The surface of the lake decreased. The canals that were filled in reached as far as the ZUS building [currently the ZUS - The Social Insurance Institution - building is located on the intersection of Czerniakowska Street and Trasa Siekierkowska - I.K.], melioration work was conducted".

27 The meadows on which the housing settlement was built "must surely have remembered the village of Czerniaków, which existed in this area from medieval times. [...] From today's perspective, the impression might be received that time was especially kind to this place, leaving it unchanged for nearly 300 years. At the time of the outbreak of the Second World War civilization had practically not reached here; and Sielce, which neighbored Czerniaków, seemed to be the last outpost of the city. Further, in the direction of Wilanów, there was an almost unbroken extent of solely fields and meadows" (Habrat 2018 p. 12; see also Warszawa naszych pradziadków..., reprint s.n., pp. 236, 268-269; Szwankowski 1970, pp. 9, 31, 33).

${ }^{28}$ Rezerwat przyrody Jeziorko Czerniakowskie, June 24, 2018, https://pl.wikipedia.org/wiki/Rezerwat_przyrody_Jeziorko_Czerni..., accessed 03.09.2018.

${ }_{29}$ Rezerwat przyrody Jeziorko Czerniakowskie, June 24, 2018., https://pl.wikipedia.org/wiki/Rezerwat_przyrody_Jeziorko_Czerni..., accessed 03.09.2018.

${ }^{30}$ It should be stressed that not all the inhabitants of this part of the capital were against the said investment. Martyna Stysło, on the basis of her own research conducted in February 2010 near Czerniakowskie Lake, gives an account of the many different attitudes she encountered. I will quote here some of the responses: "Actually that whole building doesn't bother me. Finally someone is doing something 
dual-level underground garages. There were fears that it would have a negative impact on the nearby lake ${ }^{31}$. The protests were supported by, among others, the members of the Committee for Spatial Planning and Environmental Protection of the District of Mokotów ${ }^{32}$ and persons representing the Green Mazovia Association ${ }^{33}$.

On February 18, 1987, on the basis of an order of the Minister of Environmental Protection and Natural Resources, Czerniakowskie Lake was recognized as a nature preserve, subject to protection ${ }^{34}$. On May 18, 2012, "order no. 9 of the regional director of environmental protection in Warsaw [...] on the question of establishing a plan for the protection of the "Czerniakowskie Lake nature preserve»" appeared in the Administrative Journal of the Voivodeship of Mazovia (position 4195) (Administrative Journal..., p. 1, para. 1). Annex no. 1 to the order lists various types of threats - potential and extant, internal and external - to Czerniakowskie Lake. The existing threats include "anthropopressure, comprising especially the destruction of the vegetation along the banks, the disturbance of birds, the destruction of their nesting places by people and dogs, the dumping of garbage in the reserve terrain, uncontrolled ingress to the reserve [...]" (ibidem). The potential threats were "the construction of new technical infrastructure within the reserve due to the pressure of housing construction in the surrounding areas" (ibidem).

The Plan for the Protection of Czerniakowskie Lake Nature Preserve is supposed to be in force for twenty years (Administrative Journal..., p. 1, para. 1), that is, until the year 2032. If by that time effective action has not been taken to stop the degradation of the lake and slow the negative processes, the Lake will become an "algae-laden pond", or will "simply disappear" 35.

with that overgrown meadow. After all the building will be attractive and modern. And as to the Lake... since we, the inhabitants of Bernardyńska Street, have not wrecked the lake in the course of thirty years, what will one more apartment building change?" (woman, age 28). "The Bernardyńska settlement is behind the whole affair, obviously. They always had peace and quiet out their windows, and now's there's a construction site. No one wants noise or commotion" (Stysło adds that these were the statements of two young fellows). "Unfortunately, it's already a lost cause. I was at the informational meeting about the consequences connected with the construction of these buildings. I was very interested in the matter. I don't want the reserve to suffer. In addition, I'm really fond of these meadows - I used often here often with my dog" (man, age 37). Stysło Martyna 2010, Jak uratować Jeziorko Czerniakowskie?, https://www. edutuba.pl/2010/Jak_uratowac..., accessed 10.10.2018.

${ }^{31}$ Wojtczuk Michał, November 19, 2009. Apartamentowiec nad jeziorkiem, http://www.domiporta. pl/poradnik/1,126867,7269834,Apartamento..., accessed 03.09.2018.

32 Ibidem.

${ }^{33}$ Jaszczuk Witold, Klepaczko Agata, November 19, 2009, Konflikt wokół zabudowy okolic Jeziorka Czerniakowskiego, http://zm.org.pl/?=jez_czerniakowskie-kalendarium, accessed 05.09.2018; See also, ibidem, pp. 2-4, 6-7, 12.

${ }^{34}$ Rezerwat przyrody Jeziorko Czerniakowskie, June 24, 2018, https://pl.wikipedia.org/wiki/Rezerwat_przyrody_Jeziorko_Czerni..., accessed 03.09.2018.

${ }_{35}$ Wojtczuk Michał, May 29, 2017, Jeziorko Czerniakowskie wysycha. Bez zasilania po prostu zniknie, http://warszawa.wyborcza.pl/warszawa/7,54420,21877967,jeziorko... accessed 03.09.2018. A man of around 50 years of age with whom I spoke in the summer of 2017 blamed the state of the lake on officials, who claim that the drying of the lake is a normal process and thus they make no effort to slow or stop the phenomenon. 
In the spring of 2018 the Land Management Plan for Southern Czerniaków (part of the district of Mokotów) was presented to Warsaw inhabitants. It evoked numerous controversies. A segment of the Warsaw population addressed a petition to the Governor of Mazowieckie Province, reminding him that Czerniakowskie Lake is located on the "lands of a nature reserve [...] [in which] there are many varieties of trees and shrubs, as well as providing protection for several tens of kinds of birds" ${ }^{\prime 36}$. The authors of the petition emphasized that "they want to undertake an attempt to save this as-yet-untouched enclave of wild nature, before approval [...] of the [abovementioned plan], which could lead to the degradation of the environment in that area" ${ }^{\prime 3}$. It was another in a series of protests against the construction of housing, "office buildings and apartment buildings" in the vicinity of Czerniakowskie Lake, which was supposed to "fill" the "green "hole in the city»"38.

The areas in the vicinity of the lake have been attracting the attention of investors for years. For instance, there are plans to build a complex called "Libretto Park", with a combined area of 100,000 square meters, at the intersection of Czerniakowska Street and Trasa Siekierkowska. It would have a multi-story office building with underground garages for 1,800 cars (Ilnicki 2017, p. 9). Mariusz Ilnicki claims that the effect of the investment would be, among other things, "a significant intensification of traffic and a problem with parking" (ibidem). At the same time, he emphasizes that the "development of service infrastructure" should be expected, as well as the "vitalization of the area that is today cut in two by the [Siekierkowska] motor route" (ibidem). He does not mention the impact of investments on the natural environment (the underground garage and the growth in the levels of fuel exhaust will undoubtedly hasten the process of Czerniakowskie Lake's desiccation). He also does not mention noise and its consequences (see also Ilnicki 2018) ${ }^{39}$.

If the above-mentioned plans are implemented, the Bernardyńska settlement, neighboring the Garden City of Sadyba, which was established in the interwar period, can expect large changes. New "multi-family" buildings will appear in its vicinity ${ }^{40}$. Space for the "little Sadyba bazaar", which is currently located on Konstancińska

${ }^{36}$ Mieszkańcy nie chcą bloków wokót Jeziorka Czerniakowskiego, July 2, 2018, https://warszawa.tvp. pl/37903403/mieszkancy-nie-chca-blokow-wo..., accessed 03.09.2018.

${ }^{37}$ Ibidem.

${ }^{38}$ See, e.g., Plan zagospodarowania dzikich terenów Mokotowa. Będą kolejne biurowce?, January 13, 2015, https://www.muratorplus.pl/inwestycje/inwestycje-komercyjne/plan..., accessed 03.09.2018; Jaszczuk Witold, Klepaczko Agata, November 19, 2009, Konflikt wokół zabudowy okolic Jeziorka Czerniakowskiego, http://zm.org.pl/?=jez_czerniakowskie-kalendarium, accessed 05.09.2018.

39 The problem of noise in the vicinity of Trasa Siekierkowska (including, among other places, the Bernardyńska settlement) is mentioned, for instance, in the Stanowiskou Zarządu Dzielnicy Mokotów w sprawie projektu miejscowego planu zagospodarowania przestrzennego Czerniakowa Południowego, of July 21, 2009; see Jaszczuk Witold, Klepaczko Agata, November 19, 2009, Konflikt wokół zabudowy okolic Jeziorka Czerniakowskiego, http://zm.org.pl/?jez_czerniakowskie-kalendarium, pp. 8-9, accessed 05.09.2018.

40 Czerniaków Południowy - Przyjazne nowe miasto, na które nie ma pieniędzy, April 18, 2018, http:// www.sadyba24.pl/wiadomosci/item/1845-czerniakow-polud..., accessed 03.09.2018. 
Street, would be found near the historical Bernardine monastery ${ }^{41}$. How will the investment be received by the inhabitants of the housing settlement? What impact will the investment have on the monastery buildings?

In the summer of 2018 I spoke about the planned changes with five people living within the Bernardyńska housing settlement. Three of them were against the Land Management Plan for Southern Czerniaków. One man (around 70 years of age) mentioned the expected rise in the levels of exhaust and the creation of gigantic traffic jams (I should add that already today Powsińska and Czerniakowska streets have traffic jams at various hours, and almost every day there are traffic jams on the Wisłostrada and Trasa Siekierkowska roads). Two persons called attention to the rise in noise level. A man (around 50 years of age) spoke of the quiet that had charmed him when he moved to Bernardyńska from the center of the city. His joy had not lasted long, however. The quiet ended with the construction of the Trasa Siekierkowska road. Through the open window there is a constant noise of traffic. "At night it's hard to sleep, but when there are heat waves, it's hard to shut the window. So we suffer. It's worst in the summer". A 70-year-old woman mentions the noise reaching the apartments located in the buildings that form part of the Bernardyńska settlement and are located near Powsińska Street ${ }^{42}$. The same woman, and a 70 -year-old man, say that the Plan should be implemented. In their opinion, progress can not be hindered. The city has to expand. There have to be new settlements, streets, shops - even if not everyone likes it. The protests of those who are upset by change should not be taken into account.

Some people worried about the condition of the lake, the declining water level, the increasingly striking overgrowth of the banks. These phenomena are ascribed primarily to construction (Trasa Siekierkowska, housing settlements). The plans that could contribute to saving the body of water were mentioned, although, in the opinion of two people, not everyone was interested in saving the lake. "They're waiting for the lake to dry up; then they'll be able to build what they want. We might not live to see it, but our children will live in such a devastated environment" (man, around 60 years of age). "They'll look at the lake in photos and films" (woman, around 70 years of age).

Like those protesting against the realization of the Land Management Plan for Southern Czerniaków, the interlocutors also pointed to the influence of various kinds of investments and other human activities on lowering the water in the lake, the

${ }^{41}$ Ibidem, "Czerniaków was once the property of the Czerniakowski family, and then, after passing through various hands, in the seventeenth century belonged to the Lubomirski family, including to Great Marshal of the Crown Stanisław Lubomirski, who erected a beautiful church, [...] to which he brought a relic of St. Boniface, given to him by Pope Innocent XI, and which in 1694 he placed in the cellar of the church here" (Warszawa naszych pradziadków..., reprint, s.n., p. 269). By the Church of the Bernardines "on the first Sunday after May 14" indulgences, for which Varsovians came en masse, were given in honor of St. Boniface (ibidem).

${ }^{42}$ The woman had moved to Bernardyńska from a villa district of Warsaw in the middle of the 1970s. In the beginning she was bothered by the noise, the impossibility of sleeping, of sleeping quietly. With time she grew accustomed. She sleeps with her windows open. Many of the people who visit her comment on the noise from the street. Some inhabitants of the settlement complain about the noise from the playground, the annoying sound of mowers, of leaf-blowing equipment, garbage trucks, and so forth. 
overgrowth of vegetation, and the rising level of pollution, constituting a threat to the lake's unique flora and fauna ${ }^{43}$. The harmful bacteria and blue-green algae, which caused the temporary closing of the bathing area, were also mentioned ${ }^{44}$.

\section{WHY DO WE NEED A NATURE RESERVE?}

There are twelve nature reserves in Warsaw. Until not long ago, access to seven of them was closed. Pedestrian traffic was possible in four reserves. In some, for instance, Kabacki Forest, bicycle traffic was also allowed. In the Czerniakowskie Lake reserve "walking is allowed only on designated trails; sunbathing and swimming, as well as amateur fishing, are also legal, as are horseback riding and dogs - in designated areas" (Chełmiński 2016, p. 3$)^{45}$.

From a study conducted in the spring of 2008 by Marta Panek from the Biology Department of the University of Warsaw (on a sample of 444 people encountered on the banks of Czerniakowskie Lake), it emerged that $55 \%$ of those surveyed were interested in having the area of the reserve transformed into a sports and recreation terrain, $43 \%$ wanted above all to use the bathing area, $33 \%$ of those surveyed were interested in protecting nature, and $12 \%$ were for "combining the recreational function with protection of nature" 46 . Those in favor of "protecting the [Lake] in the form of a nature preserve" were chiefly older people and anglers ${ }^{47}$. "Only a few percent of those surveyed considered that Czerniakowskie Lake should not be protected at all" The largest percentage of people with such convictions (19\%) were young people, between 16 and 20 years of age. Members of this age group "knew the least about

${ }^{43}$ Even today, in spite of the great pollutedness of the lake and its progressing degradation, it is possible to come on signs of life. "[...] The vegetation is not overgrowing the lake equally, but in parts, which means that underwater there are green corridors, like in a labyrinth. Quite a bit of the greenery, along with the duckweed create something on the order of floating islands. There are masses of fish. Unfortunately, they are not wary enough, even the pike", Odkryli wielobarwny świat $i \dot{z} y c i e$ w glębinach Jeziorka Czerniakowskiego, September 18, 2016, http://www.sadyba24.pl/component/k2/item/1349odkryli-wieloba..., accessed 11.12.2017. These words were written by Piotr Kowalski, chairman of the Wanda underwater scouts' club, who took unique photos beneath the surface of the lake.

${ }^{44}$ In the opinion of Dr. Jerzy Solon of the Institute of Geography and Land Management of the Polish Academy of Sciences, who studied the reserve in 2010, the degree of degradation is so significant that "emphasizing the richness of the area's flora and fauna [...]" must be relinquished (ibidem).

${ }^{45}$ I would add that swimming is possible solely in a designated area, that is, a guarded swimming area. In other places there are signs prohibiting bathing, but the prohibition is not respected. It is the same with the prohibition against drinking alcohol by the lake, against barbecue grills, and against walking dogs off-leash and without a muzzle.

${ }^{46}$ Użytkownicy Jeziorka chca rekreacji, a nie rezerwatu - zaskakujace wyniki badań, July 22, 2014, http://www.sadyba24.pl/wiadomosci/item/576-uzytkownicy-jeziork..., accessed 26.11.2017. The majority of people come to the lake in order to "rest passively by the beach or in the grass" or to walk (ibidem).

${ }^{47}$ Ibidem.

${ }^{48}$ Ibidem. 
the form of protection in force for Czerniakowskie Lake. Most [of them] [...] were convinced that there was a lack of any kind of legal protection" ${ }^{39}$. Panek claims that:

[...] there is a large difference between what the users of the Lake declare publicly during anti-developer actions, with the threats to the land they perceive (loss of water, construction), and how they actually make use of the reserve $e^{50}$.

The majority (65\%) of those surveyed were aware of disadvantageous changes, especially the growth in levels of pollution. Decidedly fewer people pointed to "lowering of the water levels, and destruction of vegetation and frightening birds" 51 .

The above-cited article mentions that in the course of three years the water level of the lake has dropped by 25 centimeters $^{52}$. It was noted that "to this time the blame for this state of affairs was placed on administrative officials, who allowed construction in the area and did not take visible activities to increase the inflow of water" ${ }^{\prime 2}$. It would seem, however, that the cause of certain changes within the reserve are also due, or could be due, to the "actual behavior and preferences of the lake's users" 54.

A large number of the respondents did not feel any sense of responsibility in regard to Czerniakowskie Lake and the areas in its immediate vicinity. They also did not take responsibility for their behavior and its negative impacts on the natural environment. They were aware, for instance, that there was a prohibition against lighting campfires on the reserve, and that it is forbidden to walk dogs without a muzzle, but they did not feel obliged to observe these regulations ${ }^{55}$. In the opinion of the study's author, "Czerniakowskie Lake nature reserve is threatened by the drop in the water level, excessive pressure from recreational uses, and construction on nearby land" 56 . In my view for persons with such attitudes, consumption seems more important than preservation of a unique reserve area and its environs for coming generations.

In February 2010, Martyna Stysło, whom I quoted above, asked sixty persons (13 to 17 years of age) the question "What should be done with the areas around Czerniakowskie Lake?" ${ }^{77}$ The respondents had the following choice of answers: (1) "nothing", (2) "expand the surrounding area and protect it better", (3) "create a recreational area", or (4) "build housing settlements" 58 . The majority (29 persons, that is, $48 \%$ ) stated that the area surrounding the lake should be "protected, that is, leaving it as natural as possible" $59.35 \%$ (21 of the respondents) were in favor of creating "many

\footnotetext{
${ }^{49}$ Ibidem.

${ }^{50}$ Ibidem.

${ }^{51}$ Ibidem. What percentage of the respondents formed this group is not given.

${ }^{52}$ Ibidem.

${ }^{53}$ Ibidem.

${ }^{54}$ Ibidem, emphasis mine - I.K.

55 Ibidem.

${ }^{56}$ Ibidem, emphasis mine - I.K.

57 Stysło Martyna, 2010, Jak uratować Jeziorko Czerniakowskie?, https://www.edutuba.pl/2010,Jak_ uratowac..., p. 20, accessed 10.10.2018.

${ }^{58}$ Ibidem.

${ }^{59}$ Ibidem.
} 
recreational places - courts, playing fields, a swimming pool, a park, perhaps a ministadium" ${ }^{\prime \prime} .12 \%$ (7 persons) considered that "the grounds around the reserve should be left as they are" ${ }^{61}$. In the opinion of $5 \%$ of the participants ( 3 persons), "constructing apartment buildings is the best way to manage the space" 62 .

In June 2018, a round of public consultations was begun with the aim of determining what the inhabitants of Mokotów want, including in relation to the environs of Czerniakowskie Lake. "[H]ow should this area look and what should be changed to make it a showpiece of the [...]" district? (Konsultacje 2018, p. 4). It was stated that the land by the Lake should be "adapted to the needs of the inhabitants" (ibidem); it was promised that the voices of those participating in the consultations would be taken into account in choosing of the "form of recreation suited to the place" (ibidem). When I read about this consultation, I wondered what the outcome would be, what proposals for change would be advanced, and how their implementation would affect the state of the areas by Czerniakowskie Lake and the lake itself. Would they contribute to the increase of noise? Would the respondents, like the participants in the survey conducted by Stysło, want to see the construction of "courts, playing fields, a swimming pool, a park and/or a mini-stadium"? Would there be proposals for the organization of discotheques and open-air concerts, during which the decibel levels would decidedly exceed the acceptable norms, and would the hi-fi soundscape be replaced by a lo-fi soundscape? Why was it considered that changes are needed? Who decided that it was necessary to introduce changes?

The public consultations, which were commissioned by the City of Warsaw's Sports and Recreation Center in the District of Mokotów, and conducted by the firm Pronobis Studio, were supposed to obtain an answer to the question "How should the area by Czerniakowskie Lake be changed?" ${ }^{63}$ The respondents had varying preferences for spending time on the beach by the lake. Members of the largest group (37\%) were in favor of walks. The next largest groups preferred "meetings with friends and family (18\%), swimming in the lake (12\%), sunbathing (11\%), engaging in sports (10\%), and reading (8\%)" (ibidem, p. 11). In the least numerous group (2\%), the answers were categorized as "other" and included "fishing, observing nature, recording videos, working, and sailing" (ibidem). In answering "the question of what required improvement in the said area the respondents pointed, among other things, to $[. .$.$] the state of benches, garbage disposal containers, lighting, sand, and the need$ for bike stands" (ibidem, p. 13). Attention was also drawn to the:

${ }^{60}$ Ibidem.

${ }^{61}$ Ibidem.

${ }^{62}$ Ibidem.

${ }^{63} 198$ people responded to a survey conducted in paper and electronic versions, www.konsultacje. um.warszawa.pl (Pronobis, Widzisz-Pronobis, Adamczyk 2018, pp. 7, 9). The majority of them (65\%) were women. In terms of age groups, there was a predominance of people between 26 and 45 years of age (64\%) (ibidem, p. 9). The majority of the respondents (59\%) lived within half a kilometer of the beach; $41 \%$ were people who lived at a greater distance (ibidem, p. 10), accessed 15.02.2019. 
[...] need to improve public order and security, to care for the cleanliness of the beach and entire area, to manage the existing building ${ }^{64}$, to care for the quality of the vegetation in the areas surroundings, to create a playground for children, to resolve the problem of people setting up barbecue grills within the area (ibidem).

These answers were in the group categorized as "others" (ibidem).

In answering the open question "What, in the opinion of the respondents, is lacking in the vicinity of Jeziorna Street?", the majority of people indicated a lack of "cafés, restaurants, seasonal eateries; toilets and showers; security cameras, patrols by the municipal police and infrastructure to limit the consumption of alcohol; order, cleanliness and aesthetics" (ibidem, p. 14). The lack of care for nature was spoken of, and the lack of a "playground, a specialized area for barbecue grills, a place for engaging in sports" was also mentioned (ibidem). In 11th place (out of 21) was a "quiet zone" (ibidem), in last place, "a larger beach" (ibidem). The next open question was "What do the respondents dislike in the vicinity of Jeziorna Street?" (ibidem, p. 15). The majority of people pointed to the "consumption of alcohol in the whole area, the littering of the beach and entire area, the noise, [and] barbecue grills" (ibidem) Many people were annoyed by dog excrement (which had not been removed by the animals' owners) and "car traffic along Jeziorna Street and improper parking" (ibidem).

The study showed the decided differences in the desires of the people whose houses are near the lake and those who live further away from it. The people in the latter group wanted "expanded conveniences for beach-goers" (ibidem, p. 17), the "organization of special points for barbecue grills - separated from the area and properly marked and supervised by services" (ibidem, p. 19, cf. p. 22), as well as "lifting the prohibition on the consumption of alcohol, expanding the beach, [and] the organization of mass events" (ibidem, p. 22). Those in the first group "asked for limitations on use of the beach" (ibidem), as it is connected most often with drinking alcohol and lighting barbecue grills, in spite of the prohibition (which is not enforced), and also with noise, especially from loud music during various kinds of "organized parties" (ibidem, p. 18, cf. p. 22, 28, 30,31). The authors of the report consider that "the organization of events is contrary to the nature of the area and should not occur in the reserve in its current condition" (ibidem, p. 22). Some of the respondents proposed the organization of dances by the lake (ibidem). Many people pointed to the necessity of protecting the natural attributes of the area, but the authors of the report point out that this area is not a "strict reserve" (ibidem). According to the present plans, it is meant to be "used [...] for recreational, educational, and rest-and-relaxation purposes" (ibidem).

${ }^{64}$ For ages there has been a dilapidated building near the beach. It once belonged to the WOPR (Volunteer Lifeguards) and was used for keeping recreational equipment and so forth. The building's comparatively small area means that it can not be used (after renovation) for "restrooms, changing rooms [or] facilities"; perhaps it could be used for "a storage or rental of water equipment, [...] a place for neighborhood meetings, sanitary facilities, a small eatery" (ibidem, p. 24). The owner of the building is presently the City of Warsaw. "The mayor of Mokotów [...] transferred administration of the building and nearby lot [...] to the Sports and Recreation Center", Sporny teren nad Jeziorkiem Czerniakowskim przechodzi w ręce miasta, November 2, 2017, http://www.sadyba24.pl/wiadomosci/item/1701-sportyteren-nad-je..., accessed 03.09.2018. 
How is "the balance in satisfying the needs of various groups of users and protecting the environment in the reserve" to be obtained (ibidem)? To take the matter a step further, the question could be asked of how to harmonize the contrary needs of those who like drinking and barbecuing with the needs of those who want to introduce a complete prohibition on this kind of behavior by the lake. How are the needs of lovers of quiet to be accorded with the needs of those who want to have fun with loud music? How are the desires of adherents of limiting the number of users of the terrain around the lake to be harmonized with the desires of those who would like to attract crowds here, for instance, by organizing mass events or increasing the number of rental rowboats, pedal boats, and kayaks (for such proposals, see ibidem, p. 18, 20, 29)?

People who want to relax in quiet will undoubtedly not be pleased with implementation of the respondents' proposals for the building of playgrounds, playing fields, "the construction of a rope park" (ibidem, p. 25), or the "opening of a volleyball court (for instance, on the beach)" (ibidem, p. 18). It will also be difficult for them to accept the organization of "sports and recreation courses, competitions, and sports and recreation events [...]", as provided for in the plans of the administrators of the land on which the lake is found and its surrounding areas ${ }^{65}$.

Among the participants in the consultation were proponents of quiet and those who prefer loud behavior (some even wanted mass events, which are an annoying source of noise for others, to be organized). Many inhabitants of Sadyba were in favor of "quieting the area and getting it back for the purposes of quiet recreation" (ibidem, p. 22). Their expectations are contrary to the needs of the "newcomers", whose aim is above all to have loud parties ${ }^{66}$. This could be perceived - in my opinion - as a form of "acoustic violence" (Losiak 2008, p. 256), "a violation of privacy in the phonic sphere" (ibidem, footnote 3 ) and of the border between the public and private sphere (ibidem, p. 256). The phenomenon is a frequent source of conflicts (ibidem, p. 260; see also Kabzińska 2009).

Contemporarily, the borders between "walking and recreation areas" and "trade, service, and production areas" are increasingly being blurred (Para 2012, p. 28). The trend is accompanied by the growth in noise levels, to which lovers of quiet not infrequently object. "Quieting others" is perceived as a "strategy of control, representing [for instance] a rejection of communication in public places" (Kołacki 2012, p. 66). Is forcing others to listen to loud noises, as in a lo-fi soundscape, not also a "strategy of control"? Is lifting the ban on nighttime noise in order that the regulations should not hamper those who want to have loud parties at any time of the night or day not also a "strategy of control"? ${ }^{67}$ Are we not dealing here with "acoustic violence"?

${ }^{65}$ Sporny teren nad Jeziorkiem Czerniakowskim przechodzi $w$ ręce miasta, November 2, 2017, http:// www.sadyba24.pl/wiadomosci/item/1701-sporny-teren-nad-je..., accessed 03.09.2018.

${ }^{66}$ See also, e.g., Bez głośnej muzyki, grilla i alkoholu. Pierwsze wnioski z konsultacji o Jeziorku Czerniakowskim, July 9, 2018, http://www.sadyba24.pl/wiadomosci/item/1903-bez-głośnej-muzyki..., accessed March 4, 2019; Mieszkańcy Sadyby mówią nie dla masowych atrakcji nad Jeziorkiem Czerniakowskim, November 9, 2018, http://sadyba24.pl/wiadomosci/item/2054-mieszkańcy-sadyby-mówi..., accessed 04.03.2019.

${ }^{67}$ On opposition to observing the obligatory nighttime quiet, see Kabzińska 2009. 
It is increasingly difficult to find quiet in national and scenic parks. The most common sources of noise are transportation, "motor sports, quads, snow-blowing equipment, airplanes and helicopters, loud groups of tourists, mills, air conditioners, seasonal parties" (Bernat 2011, p. 202; cf. ibidem, p. 199). In certain parks the source of noise is "a gravel quarry (Wigierski) [or] a shooting range (Drawieński)" (Bernat 2011, p. 202) ${ }^{68}$. In the vicinity of Czerniakowskie Lake, noise is caused above all by vehicles and people who are behaving loudly, including those who listen to loud music. Many people are against behavior that could have an impact on the level of noise in the vicinity of Czerniakowskie Lake. If, however, as is very likely, the proponents of changing this place into an entertainment and recreation area (with loud parties and no prohibitions at all) prevail, then the vicinity of the lake will become an example of a lo-fi soundscape. The possibility is real. It is enough to take into account the "excessive recreational pressure" and the "preferences of the lake's users", as indicated in the studies conducted by Panek and other researchers mentioned above.

In the autumn of 2018 I spoke with a 65-year-old inhabitant of the Garden City of Sadyba. The day was cloudy and cool. The woman said, "At last those pilgrimages to the lake have stopped". She claimed that crowds of people wanting to swim in the lake were "coming from all over Warsaw and its surroundings. They make noise; they litter; they often behave like savages". For many inhabitants of the Garden City, the crowds "making pilgrimage" to the lake are treated as "outsiders" who disturb the peace of the local inhabitants.

A 75-year-old woman with whom I spoke, who had been connected with Sadyba from her earliest years, said that the people who come to the lake often behave loudly, aggressively, and that "sometimes it's a monkey garden here" (see Kabzińska 2018, p. 18) ${ }^{69}$. Let the observation of Yi-Fu Tuan serve as a commentary on these statements and as a point of departure for further reflections: "People rather than things are likely to restrict our freedom and deprive us of space" (2001, p. 59). "The world feels spacious and friendly when it accommodates our desires, and cramped when it frustrates them". (ibidem, p. 65).

\section{CONCLUSION}

I sent this text to the editorial board at the beginning of May 2019. I did not know then that the possibility described in it - that the vicinity of the reserve and the reserve itself would be transformed into a lo-fi soundscape - would shortly become

${ }_{68}$ The author calls attention to the significance of quiet and its positive influence on the "quality of life of the inhabitants" (Bernat 2011, p. 202). As is known, however, not everyone considers quiet a desirable phenomenon; not everyone understands its importance (further, see Kabzińska 2005; Kabzińska 2018; Kagge 2017; Sarah, Diat 2017).

${ }^{69}$ Both women objected to noise coming both from the behavior of "outsiders" and from the inhabitants of the Garden City of Sadyba. The younger of the women claimed that increasingly loud music can be heard coming from many homes and gardens. Entertainments with loud music are organized even in preschools. "Children are no longer able to talk quietly", (cf. Kabzińska 2005; 2007). 
a reality. I believed that implementation of the Land Management Plan for Southern Czerniaków was a question of a few years.

On July 4, 2019, Warsaw city councilors decided to place the lands in the vicinity of Czerniakowskie Lake in the hands of developers. Succeeding apartment buildings and office buildings with underground garages, shopping galleries, and recreation centers will arise on the fields and meadows neighboring the reserve. New streets will appear, along which cars will travel every day without cease. A town will emerge in which several thousand people will live. The construction will undoubtedly rapidly increase the dying of the lake. Perhaps it will emerge that after some time the lake will be changed into an effluent, one of many on the map of the capital ${ }^{70}$. Even if an "enclave of quiet" is maintained, it will only be a small island - saved by a miracle - in a sea of noise.

I wonder about the sense of the "social consultation" to determine the desired direction of change for the reserve and the expectations and needs of the people for whom the place is in some manner important. What is the point of planning an investment for entertainment and recreation on lands that in a few years may only be a space dominated by noise, a lo-fi soundscape, and the memory of a nature reserve?

For the majority of the city, such a soundscape is ordinary and familiar; it is accepted by many inhabitants, who are accustomed to it. In the future will the change in the soundscape of the current reserve also be accepted? What will be the effect on perceptions of this place, attitudes toward it, and expectations in regard to it? In discussions about the future of the reserve, will the question of peace-destroying noise become as important as the degradation of the natural environment, the landscape, and the threat to the world of flora and fauna?

It's the morning of July 8, 2019 and I'm going to work. Through the windows of the bus I see hectares of fields and meadows, with groves of green trees and bushes. In the distance is the lake, which for years has served as a bathing place for Varsovians

${ }^{70}$ Such was the fate of the former Forteczna Canal, called the Bernadyńska Water. During the interwar period there was a bathing place here, whose depth in certain places reached four meters. There was boating and kayaking here; people jumped into the water. People played on the banks, making use, for instance, of the swings or of places designated for dancing. There was also a small theater (Trepka S.T. 2018 , p. 8). The 1960 s brought the "decline of the bathing place" (ibidem). A contributing factor was melioration work, which with the construction of water mains and other kinds of activities connected with urbanization of the land caused the desiccation of the body of the water (ibidem), "Bernardyńska Water suffered a complete degradation. [...] Over a length of 600 meters and a depth of 2.5 meters we have a swamp overgrown with cane, and in places the water is only 10-40 centimeters in depth. We can easily call this state an eco-catastrophe" (ibidem, see also Trepka T. 2018). I fear that Czerniakowskie Lake will share the same fate. 
and people from outside the city, who want to cool off and to enjoy various forms of relaxation. Many of them have sought quiet here.

I turn my head away. I feel a painful tightening in my throat. I've never liked goodbyes, especially those where there is no hope of a future meeting... ${ }^{71}$

\section{LITERATURE}

B e r n at S e bastia n 2011, Krajobraz dźwiękowy jutra, [in:] Niematerialne wartości krajobrazów kulturowych, Prace Komisji Krajobrazu Kulturowego [work of the Cultural Landscape Committee], no. 15, Komisja Krajobrazu Kulturowego PTG, Sosnowiec, pp. 193-205.

B e r n at S e b a stia n 2015, Wokół pojęcia soundscape. Dyskusja terminologiczna, Prace Komisji Krajobrazu Kulturowego, no. 30, pp. 45-57.

B r o n ow i c z Jan u s z 2001, Dzieje warszawskiej Sadyby, Rocznik Warszawski, vol. XXX, pp. 221-286.

Caillot Dubus Barbara, Karkowska A leksandra 2015, Banany $z$ cukrupudru, Oficyna Wydawnicza Oryginały, Warsaw.

Chełm iński Ja k u b 2016, Nowy rezerwat w Warszawie, Gazeta Wyborcza (supplement: Gazeta Stołeczna. Wydarzenia), July 16-17, 2016, p. 3.

D ziekanowska Małgor zata 2015, Przemiany audiosfery życia codziennego wsi, Przestrzeń społeczna, no. 2 (10), pp. 43-60.

Dziennik Urzędowy Województwa Mazowieckiego, Warsaw, May 18, 2012.

Faryna-Paszkiewicz Hanna, Pi otr Paszkiewicz 1985, Początki zabudowy Sadyby, Kronika Warszawy, vol. 16, no. 1-2 (61-62), pp. 153-163.

Gumiński Romuald, Jasińska Maria, Kobendza Roman 1925, Jeziorko Czerniakowskie. Studjum geograficzne, Nakładem Koła Geografów S. U. W., Warsaw.

Habrat Hubert 2018, Osiedle „Pod czachą, M6. Pismo „MSM” Energetyka, no. 5 (117) September-October, p. 12.

Harbanowicz Justyna, Janiak Agnieszka (eds.), 2012, Przestrzeń zgiełku, Wydawnictwo Naukowe Dolnośląskiej Szkoły Wyższej, Wrocław.

Il n i cki Marius z 2017, Zagłębie biurowców na Czerniakowie?, M6. Pismo MSM Energetyka, May-June, p. 9.

I l n i cki M a ri u s z 2018, Na łąkach czerniakowskich może powstać centrum biurowo-handlowe, M6. Pismo MSM Energetyka, vol. 3, no 115, May-June, p. 12.

$\mathrm{Ka}$ b z iń s k I w o n a 2005, O codziennym niedostatku ciszy i nadobfitości hałasu, Literatura ludowa, no. 2, pp. 3-14.

Ka b z ińs k a I w o n a 2007, Sąsiedztwo ciszy i hałasu, Tematy z Szewskiej, no. 1, pp. 117-124.

Ka b z iń ska I w o n a 2009, Jak pogodzić wodę z ogniem? Miłośnicy ciszy kontra wielbiciele hałasu, Zabawy i zabawki, nos. 1-4, pp. 75-99.

Ka b z i ńska I w o n a 2012, Nadwrażliwi-marginalizowana mniejszość kulturowa, [in:] Ciekawość świata, ludzi, kultur...Ksiegga Jubileuszowa ofiarowana Profesorowi Ryszardowi Kantorowi z okazji czterdziestolecia pracy naukowej, Renata Hołda, Tadeusz Paleczny (eds.), Księgarnia Akademicka, Kraków, pp. 121-139.

${ }^{71}$ At the end of September N2019, in Warsaw city hall a team was established whose task was to plan the salvation of Czerniakowskie Lake. Time will show whether the team's work will have an effect. And if it is not already too late... The change in the soundscape is another question, connected with construction and communications investments, and the emergence of various kinds of entertainment centers in the immediate vicinity of the reserve. If the reserve can not be saved, that soundscape will dominate and appropriate the lands belonging to the reserve today. How will this affect the inhabitants of Sadyba, of the Bernardyńska settlement, of Czerniaków. What impact will it have on the city space? 
Kabzińska I wo n a 2018, O ciszy i hałasie, ich doświadczaniu, definiowaniu i sposobach opisywania, Etnografia Polska, vol. 62, z. 1-2, pp. 5-23.

Kagge Erling 2017, Cisza, transl. I. Zimnicka, Muza, Warsaw.

Kasprzycki Jerzy, Stęp i é́ Marian 1982, Warszawskie pożegnania, Zakład Wydawniczo-Propagandowy PTTK, Warsaw.

Kołacki Rafał 2012, Hałas cywilizacyjny wobec estetycznych problemów słyszenia. Uwagi na temat socjologii słuchu, [in:] Przestrzeń zgiełku. Przestrzenie wizualne i akustyczne człowieka. Antropologia audiowizualna jako przedmiot i metoda badań, 3, Justyna Harbanowicz, Agnieszka Janiak (eds.), Wydawnictwo Naukowe Dolnośląskiej Szkoły Wyższej, Wrocław, pp. 57-67.

Konsultacje... 2018, Konsultacje na Mokotowie, Zmieniamy naszą okolicę. Nowy pomysł na Jeziorko Czerniakowskie i ulicę Narbutta, Mokotów, co stychać?, June 21, p. 4.

L o s i k R ob e r $\mathrm{t}$ 2008, Muzyka w przestrzeni publicznej miasta. Z badań nad pejzażem dźwiękowym Wrocławia, [in:] Dźwięk w krajobrazie jako przedmiot badań interdyscyplinarnych, Prace Komisji Krajobrazu Kulturowego, vol. XI, Instytut Nauk o Ziemi UMCS, Komisja Krajobrazu Kulturowego PTG, Lublin, pp. 253-264.

L o siak Robert 2012a, Pejzaż dźwiękowy lo-fi w przestrzeni fonicznej miasta, [in:] Przestrzeń zgiełku. Przestrzenie wizualne i akustyczne człowieka. Antropologia audiowizualna jako przedmiot i metoda badań, 3, Justyna Harbanowicz, Agnieszka Janiak (eds.), Wydawnictwo Naukowe Dolnośląskiej Szkoły Wyższej, Wrocław, pp. 11-21.

L os iak Robert 2012b, Słuchanie miasta? Wokół koncepcji badań miejskiej audiosfery, Prace kulturoznawcze, vol. 13, Acta Universitatis Wratislaviensis, no. 3366, pp. 11-15.

Losiak Robert, Tań c zuk Re nat a (eds.), 2012, Audiosfera miasta, Wydawnictwo Uniwersytetu Wrocławskiego, Wrocław.

Malec Magdalena, Klatka Sławomir, Kruk Edyta, Ryczek Marek 2017, Porównanie krajobrazów dźwiękowych wsi tradycyjnej i podmiejskiej, Woda-Środowisko-Obszary Wiejskie, vol. 17, z. 3 (59), pp. 71-84 (pdf: www. itp.edu.pl/wydawnictwo/woda; Instytut Technologiczno-Przyrodniczy w Falentach).

Para P iotr 2012, Przestrzeń zgiełku a społeczne interakcje, [in:] Przestrzeń zgiełku. Przestrzenie wizualne i akustyczne człowieka. Antropologia audiowizualna jako przedmiot i metoda badań, 3, Justyna Harbanowicz, Agnieszka Janiak (eds.), Wydawnictwo Naukowe Dolnośląskiej Szkoły Wyższej, Wrocław, pp. 23-32.

P i a s e $\operatorname{Pr}$ z e m e k 2015, Jeziorko Czerniakowskie. Mapa ścieżki edukacyjnej, drawings: Tratwa Artystów, Fundacja Ja Wisła, Warsaw.

S a rah Robert, Di at Ni col a s 2017, Moc milczenia. Przeciw dyktaturze hałasu, transl. A. Kuryś, Wydawnictwo Sióstr Loretanek, Warsaw.

S chafer Murray Ray mond 1970, The book of noise, Wellington, New Zealand, Price Milburn.

S chafer Murray R a y m ond 1973, The music of the environment, Vienna, Universal Edition.

Schaffer Murray Raymond 1977, The tuning of the world, New York, Knopf; Toronto, McClelland and Steward Ltd.

S chaffer Murray R a y m ond 1982, Muzyka środowiska, tłum. Danuta Gwizdalanka, Res Facta, no. 9, pp. 288-315.

Stanisz Agata 2017, Field recording jako metoda etnografii poprzez dźwięk, Przegląd Kulturoznawczy, no. 1 (31), pp. 1-19.

S zwa n kowski Euge ni us z 1970, Ulice i place Warszawy, Państwowe Wydawnictwo Naukowe, Warsaw, 2nd edition, corrected and supplemented.

Trepka Stanisław Tadeusz, Fosa Forteczna vel Woda Bernardyńska, M6. Pismo MSM Energetyka, no. 2 (114), March-April 2018, p. 8 (first printing: Nasza Gazeta Sadyba, October 1998).

Tre p ka To mas z 2018, Dlaczego nie ma wody w Bernardyńskiej Wodzie?, M6. Pismo MSM Energetyka, no. 3 (115), May-June, p. 8. 
Warszawa naszych pradziadków... 1893 (reprint, s.n), Warszawa naszych pradziadków. Ilustrowany przewodnik w podróżach. Ilustrowany przewodnik po Warszawie wraz z treściwym opisem okolic miasta [reprint], Nakład Redakcyi „Wędrowca”, Warsaw, RePrint Drukarnia, Warsaw.

Wrzeszcz Maciej 2000, Trudne półwiecze, [in:] W służbie Bogu i ludziom. 50 lat parafii p.w. św. Tadeusza Apostoła na warszawskiej Sadybie, Maciej Wrzeszcz (ed.), Parafia Rzymsko-Katolicka św. Tadeusza Apostoła, Warsaw, pp. 31-110.

Y i - F u Tu a n 2001, Space and Place: The Perspective of Experience, University of Minnesota Press, Minneapolis.

\section{Internet sources}

Czerniaków Południowy - Przyjazne nowe miasto, na które nie ma pieniędzy, April 18, 2018, http://www. sadyba24.pl/wiadomosci/item/1845-czerniaków-połud..., accessed 03.09.2018.

Ekspertyza - bilans wody Jeziorka Czerniakowskiego w Warszawie, 2009, Dariusz Górski, Katedra Inżynierii Wodnej i Rekultywacji Środowiska SGGW, Warsaw, www.mokotow.waw.pl/mokotow/web/ uploads/pub/pages/page_366/text_images/Eksperyza..., accessed 01.10.2018.

Hall Karolina, Rezerwat Jeziorko Czerniakowskie, http://panorama.varsovia.pl/varsovia/index. php-frame+main\&map..., accessed 03.09.2018.

Jaszczuk Witold, Klepaczko Agata, November 19, 2009, Konflikt wokót zabudowy okolic Jeziorka Czerniakowskiego, http://zm.org.pl/?=jez_czerniakowskie-kalendarium, accessed 05.09.2018.

Jeziorko Czerniakowskie wysycha. Jeśli nie będzie zasilane w wodę, to zaniknie!, 27.02.2017, https://mokotow. $\mathrm{pl} /$ artykul/jeziorko-czerniakowskie/139753, accessed 04.10.2018.

Mieszkańcy nie chca bloków wokót Jeziorka Czerniakowskiego, 2.07.2018, https://warszawa.tvp. pl/37903403/mieszkancy-nie-chca-blokow-wo..., accessed 03.09.2018.

Obronić osiedle Bernardyńska; 31.12.2011 - 26.12.2014, http://bernardynska.blogspot.com/, accessed 17.03.2017.

Odkryli wielobarwny świat i życie w głębinach Jeziorka Czerniakowskiego, 18.09.2016, http://www. sadyba24.pl/component/k2/item/1349-odkryli-wieloba..., accessed 11.12.2017.

Osiedle Sadyba, http://www.mokotow.waw.pl/strona-178-osiedle_sadyba.html, accessed 17.07.2017.

Plan zagospodarowania dzikich terenów Mokotowa. Będq kolejne biurowce?, 13.01.2015, https://www. muratorplus.pl/inwestycje-komercyjne/plan..., accessed 03.09.2018.

Pronobis Grzegorz, Widzisz-Pronobis Sylwia, Adamczyk Jakub, September, 2018, Coraz lepszy Czerniaków. Jak zmienić teren przy Jeziorku Czerniakowskim? Raport z konsultacji społecznych dot. zagospodarowania terenu przy Jeziorku Czerniakowskim, Warsaw, pdf., accessed 15.02.2019.

Raport SGGW - wysychanie Jeziorka Czerniakowskiego radykalnie przyspieszyło, 17.10.2016, Wydział Budownictwa i Inżynierii Środowiska SGGW, Warsaw. The report was prepared by a team directed by Michał Wasilewicz, www.sadyba24.pl/component,/k2/item/1400-tylko-u-nas-raport-SGGWwysychanie-jeziorka-czerniakowskiego-radykalnie-przyspieszyło, accessed 11.12.2017; see also: http://mokotow.waw.pl/strona-363-ekspertyzy-i-publikacje.html, accessed 11.12.2017.

Rezerwat przyrody Jeziorko Czerniakowskie, June 24, 2018, https://pl.wikipedia.org/wiki/Rezerwat_przyrody_Jeziorko_Czerni..., accessed 03.09.2018.

Spokój ponad wszystko. Urzędnicy popierają mieszkańców w walce o przyszłość pól nad Jeziorkiem Czerniakowskim; June 25, 2016, http://sadyba24.pl/wiadomosci/item/1167 - spokoj-ponad-wszystko-u..., accessed 17.03.2017.

Sporny teren nad Jeziorkiem Czerniakowski przechodzi w ręce miasta, 02.11.2017, http://www.sadyba24. $\mathrm{pl} /$ wiadomosci/item/1701-sporny-teren-nad-je..., accessed 03.09.2018.

Strona internetowa Towarzystwa Społeczno-Kulturalnego Miasto-Ogród Sadyba, http://www.miasto-ogrod.sadyba.waw.pl/index.php.

St y sło Mart y n a, 2010, Jak uratować Jeziorko Czerniakowskie?, https://www.edutuba.pl/2010,Jak_ uratowac..., accessed 10.10.2018. 
Urzykow ski To m a s, Oficerska Sadyba i Miasto Ogród Czerniaków, May 8, 2008, http://warszawa. wyborcza.pl/warszawa/1,89378,5193535.html, accessed 7.12.2017.

Użytkownicy Jeziorka chca rekreacji, a nie rezerwatu - zaskakujące wyniki badań, July 22, 2014, http:// www.sadyba24.pl/wiadomosci/item/576-uzytkownicy-jeziork..., accessed 26.11.2017.

Woj tc z u k M i ch ał, November 19, 2009, Apartamentowiec nad jeziorkiem, http://www.domiporta. pl/poradnik/1,126867,7269834,Apartamento..., accessed 09.05.2018.

Wo j t c z u k M i ch ał, May29, 2017, Jeziorko Czerniakowskie wysycha. Bez zasilania po prostu zniknie, http://warszawa.wyborcza.pl/warszawa/7,54420,21877969,jeziorko..., accessed 03.09.2018.

IWONA KABZIŃSKA

\section{THE DYING OF CZERNIAKOWSKIE LAKE, THE DYING OF QUIET: FROM A HI-FI TO A LO-FI SOUNDSCAPE}

Key words: hi-fi and lo-fi soundscapes, Nature Reserve, Czerniakowskie Lake, threats (a.o. desiccation, pressure from recreational uses, construction investments), Warsaw

Raymond Murray Schafer, a pioneer in research on the soundscape, distinguished between hi-fi and lo-fi soundscapes. The hi-fi soundscape is characterized by natural sounds, recognizable as acoustic signals. Such a soundscape has room for quiet. The lo-fi soundscape is dominated by artificial, mechanical, aggressive, irritating sounds, or noise. The emergence of this type of soundscape has been facilitated by the development of industry, by urbanization, by the realization of succeeding investments in transportation, trade, and entertainment, and by the universality of various kinds of "loud" equipment in households and the public sphere.

As an example of passage from a hi-fi to a lo-fi soundscape, the author explains the causes for the degradation of the Czerniakowskie Lake nature reserve. The causes include, above all, the construction of succeeding housing settlements near the body of water, the nearness of busy communications arteries, and the pressure to increase the reserve's use for entertainment and recreation. These activities not only have a disadvantageous impact on the natural environment, but they also contribute to the production of noise, which drives out the quiet.

The author notes the varying attitudes to changes to the reserve and various visions and expectations for its future. Whether the reserve will be changed entirely into a lo-fi soundscape will depend on the aims and plans that are implemented. Will the traits of a hi-fi soundscape become a phenomenon entirely of the past, of memories and reflections on the changes undergone by a place with which our fates are connected?

Author's address

Iwona Kabzińska, prof. dr hab.

Institute of Archaeology and Ethnology PAS

Al. Solidarności 105, 00-140 Warszawa

E-mail: red_etno@iaepan.edu.pl

ORCID: 0000-0002-7709-9999 